\title{
A study of the role of proteinorrhoea (protein-losing gastro-enteropathy) in bilharzial hepatic fibrosis
}

\author{
M. EL-SAYED AND M. ESSAM FIKRY \\ From the Gastro-Enterology Research Centre, \\ the Department of Medicine, Alexandria University, Egypt
}

EDITORIAL SYNOPSIS This study does not demonstrate any proteinorrhoea (protein-losing gastroenteropathy) in the genesis of hypoalbuminaemia in patients suffering from portal hypertension due to schistosomal (bilharzial) hepatic fibrosis with and without ascites.

Hypoproteinaemia is present in many patients suffering from schistosomal (bilharzial) hepatic fibrosis, especially when associated with ascites. In most patients with hypoproteinaemia undergoing treatment on a well-balanced diet the fall in serum proteins can be corrected except in a small group of cases. Hypoproteinaemia, mainly hypoalbuminaemia, cannot be ascribed to diminished protein synthesis, which remains within normal limits as does parenchymal liver function in patients with bilharzial hepatic fibrosis till the terminal stage (Salah, 1962).

Loss of proteins into the gastro-intestinal tract has been shown to be a major factor in the hypoproteinaemia associated with regional enteritis (Steinfeld, Davidson, and Gordon, 1957), ulcerative colitis (Holman, Nickel, and Sleizenger, 1959), sprue (Parkins 1960), gastric neoplasm (Schwartz and Jarnum, 1959), giant hypertrophy of the gastric mucosa (Chokas, 1959), hypertrophic gastritis (Citrin, Stirling, and Halsted, 1957), congestive heart failure, constrictive pericarditis (Davidson, Waldmann, Goodman, and Gordon, 1961), and the syndrome of idiopathic hypercatabolic hypoproteinaemia (Gordon, 1959; Schwartz and Jarnum, 1959).

Several methods have been employed to study this phenomenon. Paper electrophoresis and immunophoresis have been used to determine the presence of autogenous human albumins and globulins in intestinal juices (Schwartz and Jarnum, 1959; Gross, Embree, Bally, Shipp, and Thorn, 1960). But such methods are mainly qualitative. Gordon (1959) used radio-iodinated polyvinylpyrrolidone and Schwartz and Thomsen (1957) radioiodinated human serum albumin, but Waldmann (1961) used ${ }^{51} \mathrm{Cr}$-labelled albumin in attempts to study intestinal protein loss quantitatively.
MATERIAL AND METHODS

This study includes 16 patients suffering from schistosomal hepatic fibrosis with various degrees of portal hypertension, 13 of whom had ascites. They were chosen from out-patients and were admitted to the gastroenterology research centre of the department where they were carefully studied. Liver biopsy was done to assess the degree of hepatic fibrosis and graded accordingly (Zaher, 1956). The portal pressure was measured by the splenic percutaneous route in six patients. None of the patients had any evidence of gastro-intestinal bleeding.

Another group of four patients suffering from generalized oedema due to the nephrotic stage of glomerulo-nephritis is included in this study, with the idea of comparing the results in the two groups of patients, both presumably having oedema of the mucous membrane of the gut and hypoproteinaemia.

The normal value for radio-iodinated polyvinylpyrrolidine ( ${ }^{131}$ I-P.V.P.) loss in the gastro-intestinal tract was tested in one well Egyptian, in whom it was found to be normal.

Proteinorrhoea in these patients was studied using P.V.P. which is a synthetic polymer of molecular weight averaging about 4000 . It has been used as a plasma substitute, but, unlike albumin, it is unaffected by gastric juice and appears not to be absorbed from the gastrointestinal tract. These properties make it possible to recover P.V.P. in the faeces when it is excreted in the gut.

The patients were given sufficient potassium iodide two days before and during the period of faecal collection to prevent thyroid uptake of any iodide that might be liberated from the substance injected, although human and animal studies of thyroid radioactivity after parenteral injection of ${ }^{131}$ I- P.V.P. have indicated that without this precaution only traces of radioactivity can accumulate (Gordon, 1959). An amount of ${ }^{131}$ I- P.V.P. containing $20 \mathrm{mc}$. of radioactivity was injected intravenously in each subject. The faecal specimens were collected over 96 hours in gallon-size cans and treated with $20 \mathrm{~g}$. phenol to arrest 
bacterial fermentation. When the collections were completed the faeces were adjusted to a standard weight with water and homogenized by a mechanical shaker, special care being taken to avoid contamination of the stools with urine as the latter contains large amounts of radioactivity and very small amounts of urine contaminating the stools will cause erroneous results. The specimens were assayed in a scintillation counter and the faecal ${ }^{131}$ I- P.V.P. excretion was expressed as a percentage of the dose administered.

The ${ }^{131}$ I- P.V.P. was used within six days of its preparation, thus avoiding any possible dialysis; further, in two patients a dose of $100 \mathrm{mc}$. was used to avoid any possible factor of dialysis affecting the results.

\section{RESULTS}

All the patients included in this study had hypoproteinaemia which did not respond to a hospital diet containing a high protein content. The serum proteins ranged between 3.5 and $5.7 \mathrm{~g} . \%$ (only cases 5 and 11 had serum proteins values of $7 \cdot 2$ and $6.5 \mathrm{~g} . \%$ respectively).

Table I gives the values for serum proteins, albuminuria, oedema, the percentage recovery of ${ }^{131}$ I- P.V.P. from the stools, grading of fibrosis, and degree of portal hypertension. Table II shows the range and means of the percentage of recovery of 131I- P.V.P. in patients with bilharzial hepatic fibrosis and those of patients in the nephrotic stage of glomerulonephritis. The range and mean of these two groups are normal, considering both Gordon's figures (1959) and our own.
TABLE II

RESULTS OF ${ }^{131}$ I- P.V.P. TEST FOR PROTEINORRHOEA IN CERTAIN DISEASES

\begin{tabular}{lccc} 
Diagnosis & $\begin{array}{l}\text { No. of } \\
\text { Cases }\end{array}$ & $\begin{array}{l}\text { 131I-P.V.P. } \\
\text { Recovered in } \\
\text { Stools (\%) }\end{array}$ & $\begin{array}{l}\text { Mean Percen } \\
\text { 131 I-P.V.P. } \\
\text { Recovered } \\
\text { Stools }\end{array}$ \\
\hline $\begin{array}{l}\text { Bilharzial hepatic fibrosis } \\
\text { and splenomegaly }\end{array}$ & 3 & $0.35-0.90$ & 0.53 \\
$\begin{array}{l}\text { Bilharzial hepatic fibrosis, } \\
\text { splenomegaly, and ascites }\end{array}$ & 13 & $0-0.50$ & 0.20 \\
$\begin{array}{l}\text { Nephrotic stage of } \\
\text { glomerulo-nephritis }\end{array}$ & 4 & $0-0.69$ & 0.26 \\
$\begin{array}{l}\text { Normal Egyptian } \\
\text { Normal (Gordon, 1959) }\end{array}$ & 1 & $0-1.5$ & 0.34 \\
1.0
\end{tabular}

DISCUSSION

The lesions in schistosomal (bilharzial) hepatic fibrosis are mainly and primarily mesenchymal. The fibrosis occurring along the portal tracts results in splinting and constriction of the portal vessels inside the liver, with the development of portal hypertension as well as congestion of the portal bed which leads to congestion and oedema of the gastric and intestinal mucous membranes drained by the portal system (Pollack and Gerber, 1943).

Hypoalbuminaemia is a common finding in these patients, more so in patients with ascites. It may be due to a deficient diet in some patients as it improves on hospital diets. In addition, in patients with ascites, the hypoalbuminaemia is due to sequestration of a large amount of albumin in the ascitic fluid; defective protein synthesis cannot be considered as a factor in its production as this disease is a mesenchymal

TABLE I

RESULTS OF RECOVERY OF ${ }^{131}$ I- P.V.P. FROM STOOLS IN CERTAIN DISEASES IN RELATION TO BLOOD PROTEINS, ALBUMINURIA, OEDEMA, DEGREE OF HEPATIC FIBROSIS, AND PORTAL PRESSURE

\begin{tabular}{|c|c|c|c|c|c|c|c|c|}
\hline $\begin{array}{l}\text { Case } \\
\text { No. }\end{array}$ & Diagnosis & $\begin{array}{l}\text { Plasma } \\
\text { Proteins } \\
(\mathrm{g} . \%)\end{array}$ & $\begin{array}{l}\text { Dose of } \\
{ }^{131} I-P . V . P . \\
(u c)\end{array}$ & $\begin{array}{l}\%{ }^{131} I- \\
\text { P.V.P. in } \\
\text { Stools to } \\
\text { Dose } \\
\text { Given }\end{array}$ & Oedema & $\begin{array}{l}\text { Albumin- } \\
\text { uria } \\
\text { (g./litre })\end{array}$ & $\begin{array}{c}\text { Grade of } \\
\text { Fibrosis }\end{array}$ & $\begin{array}{l}\text { Portal } \\
\text { Pressure } \\
\text { (mm. } \\
\text { water) }\end{array}$ \\
\hline 1 & Bilharzial hepatic fibrosis and splenomegaly & $5 \cdot 5$ & 20 & $0 \cdot 35$ & - & 0.5 & & \\
\hline 2 & Bilharzial heptaic fibrosis and splenomegaly & $5 \cdot 5$ & 20 & $0 \cdot 35$ & - & - & & \\
\hline$\overline{3}$ & Bilharzial hepatic fibrosis and splenomegaly & $5 \cdot 5$ & 100 & 0.9 & - & - & & \\
\hline 4 & Bilharzial hepatic fibrosis, splenomegaly, and ascites & $3 \cdot 5$ & 20 & 0.50 & + & - & & \\
\hline 5 & Bilharzial hepatic fibrosis, splenomegaly, and ascites & $7 \cdot 2$ & 20 & $0 \cdot 19$ & - & 0.5 & & \\
\hline 6 & Bilharzial hepatic fibrosis, splenomegaly, and ascites & $3 \cdot 7$ & 20 & $0 \cdot 27$ & + & $0 \cdot 25$ & & \\
\hline 7 & Bilharzial hepatic fibrosis, splenomegaly, and ascites & 4.5 & 20 & $0 \cdot 19$ & + & $2-325$ & III & 310 \\
\hline 8 & Bilharzial hepatic fibrosis, splenomegaly, and ascites & $4 \cdot 5$ & 20 & $0 \cdot 14$ & + & - & II & 480 \\
\hline 9 & Bilharzial hepatic fibrosis, splenomegaly, and ascites & $5 \cdot 2$ & 20 & 0.38 & ++ & - & & 456 \\
\hline 10 & Bilharzial hepatic fibrosis, splenomegaly, and ascites & $3 \cdot 5$ & 20 & 0.46 & + & - & & \\
\hline 11 & Bilharzial hepatic fibrosis, splenomegaly, and ascites & $6 \cdot 5$ & 20 & 0.0 & + & - & II & 360 \\
\hline 12 & Bilharzial hepatic fibrosis, splenomegaly, and ascites & $5 \cdot 7$ & 20 & 0.0 & - & - & 111 & 410 \\
\hline 13 & Bilharzial hepatic fibrosis, splenomegaly, and ascites & $5 \cdot 5$ & 20 & $0 \cdot 0$ & - & 0.5 & & \\
\hline 14 & Bilharzial hepatic fibrosis, splenomegaly, and ascites & $5 \cdot 5$ & 100 & 0.54 & - & 0.5 & I & 260 \\
\hline 16 & Bilharzial hepatic fibrosis, splenomegaly, and ascites & $5 \cdot 7$ & 20 & 0.0 & - & - & & \\
\hline 17 & Subchronic nephritis & $3 \cdot 5$ & 20 & $0 \cdot 69$ & $+t+$ & $4-6$ & & \\
\hline 18 & Subacute nephritis & $5 \cdot 7$ & 20 & 0.0 & +1 & $4-6$ & & \\
\hline 10 & Subacute nephritis & 3.7 & 20 & 0.0 & $\begin{array}{l}+1 \\
++\end{array}$ & $3 \cdot 5-5$ & & \\
\hline 20 & Subchronic nephritis & $4 \cdot 5$ & 20 & 0.35 & $\begin{array}{r}t+ \\
+t+\end{array}$ & $4-8$ & & \\
\hline
\end{tabular}


disease with preservation of the liver parenchymal functions until the very end, when the hepatic lobule is markedly constricted by the fibrotic process or until an additional burden is added, for example, bleeding from gastro-oesophageal varices or tapping of the ascitic fluid. This observation has been repeatedly proved in such patients (Salah, 1962).

The demonstration of loss of protein from the gastro-intestinal tract in certain disorders has lead us to study this mechanism as a possible explanation of the hypoalbuminaemia in some of these patients. The presence of congestion and oedema of the gastro-intestinal mucosa could be a possible pathological route through which protein could be lost. Reports of other diseases associated with protein loss, such as congestive heart failure (Davidson $e t$ al., 1961), and associated with oedema of the gastrointestinal mucosa, is a further similarity.

However, the negative results in this group of cases of bilharzial hepatic fibrosis with and without ascites militate against the role of congestion and oedema of the gastro-intestinal mucosa in the production of proteinaemia. Support for this hypothesis comes also from the study of patients suffering from generalized oedema and hypoalbuminaemia due to the nephrotic stage of glomerulo-nephritis. In this group there was no protein loss through the gastro-intestinal tract in spite of the marked oedema. Furthermore, in the four patients in congestive heart failure reported by Davidson et al. (1961), two had normal values nine days before the operation; 0.6 and $0.2 \%{ }^{131}$ I- P.V.P. was recovered in cases 1 and 3 respectively. In addition these patients suffered from a disease which not only caused congestion and oedema of the gastro-intestinal mucosa, but also and more importantly resulted in hypoxia of the tissues, which may be the main cause of protein loss in congestive heart failure. Moreover in congestive heart failure and constrictive pericarditis the portal obstruction responsible for the portal hypertension is postsinusoidal resulting in adding to the lymphatic congestion and leakage due to obstruction of the hepatic vein. Lymphatic congestion and leakage may occur in the intestines as well as in the peritoneal cavity and consequently proteins may appear in the faeces of patients suffering from congestive heart failure and constrictive pericarditis.

As a consequence of negative evidence of the role of congestion in producing proteinorrhoea, in all the patients studied no correlation could be found between proteinorrhoea and the degree of hepatic fibrosis to this non-existent manifestation, and another mechanism for hypoproteinaemia must be looked for elsewhere.

\section{CONCLUSIONS}

Protein loss from the alimentary tract in 16 patients suffering from schistosomal (bilharzial) hepatic fibrosis with hypoproteinaemia was studied.

The results with the ${ }^{131}$ I- P.V.P. technique show that there is no abnormal protein loss from the gastro-intestinal mucosa indicating that portal hypertension and congestion is not the cause of hypoproteinaemia. The mechanism of hypoproteinaemia in these patients has to be looked for elsewhere.

Oedema of the gastro-intestinal mucosa as a cause of protein loss was also studied in four patients with generalized oedema due to the nephrotic stage of glomerulo-nephritis; they also showed no evidence of protein loss, eliminating oedema as the mechanism.

This work was done under the direction and supervision of Professor M. Salah, in charge of the Department of Medicine.

We wish to thank Dr. R. S. Gordon for the supply of polyvinylpyrrolidone.

\section{REFERENCES}

Chokas, W. V., Connor, D. H., and Innes, R. C. (1959). Giant hypertrophy of the gastric mucosa, hypoproteinemia and edema (M.enetrier's disease). Amer. J. Med., 27, 125-131.

Citrin, Y., Sterling, K., and Halsted, J. A. (1957). The mechanism of hypoproteinemia associated with giant hypertrophy of the gastric mucosa. New Engl. J. Med., 257, 906-912.

Davidson, J. D., Waldmann, T. A., Goodman, D. S., and Gordon, R. S., Jr., (1961). Protein-losing gastroenteropathy in congestive heart-failure. Lancet, 1, 899-902.

Gordon, R. S., Jr., (1959). Exudative enteropathy: abnormal permeability of the gastrointestinal tract demonstrable with labelled polyvinylpyrrolidone. Ibid., 1, 325-326.

Gross, P. A. M., Embree, L. J., Bally, P., Shipp, J. C., and Thorn, G.W. (1960). Hypoalbuminemia (with anasarca) due to hypercatabolism, serum protein exudation into the gastrointestinal tract, increased capillary permeability and hypoanabolism. Amer. J. Med., 29, 386-404.

Holman, H., Nickel, W. F., Jr., and Sleisenger, M. H. (1959). Hypoproteinemia antedating intestinal lesions, and possibly due to excessive serum protein loss into the intestine. Amer. J. Med., 27, 963-975.

Parkins, R. A. (1960). Protein-losing enteropathy in the sprue syndrome. Lancet, 2, 1366-1369.

Pollack, A. D., and Gerber, I. E. (1943). Abdominal visceral lesions associated with primary disease of the liver. Arch. Path., 36, 608-611.

Salah, M. (1962). The bilharzial liver. Alexandria med. J., 8, 177-194.

Schwartz, M., and Thomsen, B. (1957). Idiopathic or hypercatabolic hyperproteinaemia. Brit. med. J., 1, 14-17.

-, and Jarnum, S. (1959). Gastrointestinal protein loss in idiopathic (hypercatabolic) hyperproteinaemia. Lancet, 1, 327-330.

Steinfeld, J. L., Davidson, J. D., and Gordon, R. S., Jr. (1957). A mechanism for hypoalbuminemia in patients with ulcerative colitis and regional enteritis. J. clin. Invest., 36, 931.

,,--- and Greene, F. E. (1960). The mechanism of hypoproteinemia in patients with regional enteritis and ulcerative colitis. Amer. J. Med., 29, 405-415.

Waldmann, T. A. (1961). Gastrointestinal protein loss demonstrated by ${ }^{31}$ Cr-labelled albumin. Lancet, 2, 121-123.

Zaher, R. A. (1956). Evaluation of various methods of measurement of portal hypertension in bilharzial hepatic fibrosis. M.D. thesis presented to the Faculty of Medicine, Alexandria University, Alexandria, Egypt. 